\title{
The Involvement of Glucose Metabolism in the Regulation of Inducible Nitric Oxide Synthase Gene Expression in Glial Cells: Possible Role of Glucose-6-Phosphate Dehydrogenase and CCAAT/Enhancing Binding Protein
}

\author{
Je-Seong Won, ${ }^{1,2}$ Yeong-Bin Im, ${ }^{1}$ Lyndon Key, ${ }^{1}$ Inderjit Singh, ${ }^{1}$ and Avtar K. Singh ${ }^{2,3}$ \\ Departments of ${ }^{1}$ Pediatrics and ${ }^{2}$ Pathology, Medical University of South Carolina, Charleston, South Carolina 29425, and ${ }^{3}$ Laboratory Medicine Service, \\ Ralph Johnson Veterans Affairs Medical Center, Charleston, South Carolina 29425
}

\begin{abstract}
In rat glial cells the lipopolysaccharide (LPS)-induced inducible nitric oxide synthase (iNOS) gene expression was enhanced by extracellular glucose concentration in a dose-dependent manner. On the other hand, 2-deoxy-D-glucose decreased the LPS-induced iNOS gene expression even in the presence of glucose $(6 \mathrm{gm} / \mathrm{l})$, suggesting that glucose metabolism is linked to the regulation of iNOS gene expression. The intracellular NADPH/NADP ${ }^{+}$directly correlated with the extracellular glucose concentration, and the reduction of NADPH generation via a block of glucose-6-phosphate dehydrogenase (G6PD) by treatment with dehydroepiandrosterone or the antisense DNA oligomer of G6PD mRNA resulted in the inhibition of iNOS gene expression. Gel shift assays showed that CAAT/enhancing binding protein $(\mathrm{C} / \mathrm{EBP})$, rather than $\mathrm{AP}-1$ or NF- $\kappa \mathrm{B}$, correlated better with a glucose-dependent increase in iNOS gene expression. The induction of C/EBP DNA binding activity by LPS and glucose was attributable mainly to the increase in C/EBP- $\delta$ protein. The cotransfection with wild-type $\mathrm{C} / \mathrm{EBP}-\delta$ increased the iNOS promoter activity to the level achieved with a higher glucose concentration in the presence of LPS. Therefore, our results suggest that $\mathrm{C} / \mathrm{EBP}-\delta$ may be a critical mediator in glucose-mediated regulation of iNOS gene expression.
\end{abstract}

Key words: C/EBP; astrocytes; glucose; G6PD; iNOS; NADPH; NF- $\kappa \mathrm{B}$; nitric oxide

\section{Introduction}

Clinical studies have suggested that mortality and morbidity are increased in stroke patients with high plasma glucose levels (Candelise et al., 1985). Consistent with these observations, acute hyperglycemia is detrimental when ischemia is followed by reperfusion in focal ischemia animal models (Nedergaard, 1987; Prado et al., 1988), whereas fasting before transient cerebral ischemia reduces infarct volume (Go et al., 1988; Yip et al., 1991). In line with these reports, insulin has been known to reduce postischemic damage (Voll and Auer, 1988; Hamilton et al., 1995). Although there is evidence that insulin may play a role via interaction with insulin-like growth factor (IGF)-1 receptors in global ischemia models (Zhu and Auer, 1994), it also has been known that the neuroprotective effect of insulin is attributable to the reduced peripheral level of glucose in focal ischemia animal models (Hamilton et al., 1995).

To understand how hyperglycemia or hypoglycemia affects ischemia-mediated outcomes, we hypothesized that extracellular

Received Aug. 12, 2002; revised May 27, 2003; accepted June 5, 2003.

These studies were supported by National Institutes of Health Grants NS-22576, NS-34741, NS-37766, and NS-40810. We are thankful to Dr. Shailendra Giri for cooperation in this study, Dr. Ernest Barbosa and Dr. Anne G. Gilg for proofreading this manuscript, and Joyce Bryan and Hope Terry for laboratory and secretarial assistance, respectively.

Correspondence should be addressed to Dr. Avtar K. Singh, Department of Pediatrics, Medical University of South Carolina, Clinical Science Building, Room 316, 171 Ashley Avenue, Charleston, SC 29425. E-mail: singhi@musc.edu. Copyright $\odot 2003$ Society for Neuroscience $\quad$ 0270-6474/03/237470-09\$15.00/0 glucose may affect brain damage by the regulation of the inducible or immunological isoform of nitric oxide (NO) synthase (iNOS) gene expression, because iNOS has been known to be involved in the mechanisms of cerebral ischemic insult (Iadecola, 1999; O’Mahony and Kendall, 1999). Indeed, inhibition of iNOS activity or null mutation of iNOS gene reduces susceptibility to focal cerebral ischemia (Iadecola et al., 1997). However, understanding the relationship between hyperglycemic or hypoglycemic cerebral ischemia and the expression of iNOS gene expression in neuropathological conditions remains incomplete.

In contrast to neuronal and endothelial NOS, iNOS is regulated mainly at the transcriptional level (Nathan, 1992; Jaffrey and Snyder, 1995) by several transcriptional factors such as nuclear transcription factor- $\kappa \mathrm{B}(\mathrm{NF}-\kappa \mathrm{B})$, Fos/Jun, CCAAT/enhancer binding protein $(\mathrm{C} / \mathrm{EBP})$, interferon- $\gamma(\mathrm{IFN}-\gamma)$ activation site (GAS), and IFN regulatory factor (IRF) (Gao et al., 1997; Spink and Evans, 1997; Eberhardt et al., 1998; Marks-Konczalik et al., 1998; Zhang et al., 1998). Because some of these transcription factors (AP-1, NF- $\kappa \mathrm{B}$, and $\mathrm{C} / \mathrm{EBP}$ ) are reported to be regulated by hyperglycemia (Morigi et al., 1998; Zador et al., 1998; Weigert et al., 2000), there is a possibility that glucose may be involved in the regulation of iNOS gene expression via the regulation of these transcriptional factors.

In the present study we examined the influence of glucose on the induction of iNOS gene expression in glial cells and also sought to determine the transcriptional factors and signaling 
mechanisms involved in glucose-mediated upregulation of iNOS gene expression. We report that extracellular glucose upregulated the LPS-induced expression of iNOS in a dose-dependent manner, whereas 2-deoxy-D-glucose decreased the LPS-induced iNOS expression. This increase in iNOS expression was mediated by the transactivation of $\mathrm{C} / \mathrm{EBP}-\delta$ via the pentose phosphate pathway (PPP).

\section{Materials and Methods}

Isolation and maintenance of primary rat astrocytes and C6 rat glioma cells. Astrocytes were prepared from rat cerebral tissue as described by McCarthy and de Vellis (1980). Cells were maintained in DMEM containing $3 \mathrm{gm} / \mathrm{l}$ glucose, $5 \%$ fetal bovine serum (FBS), and $10 \mu \mathrm{g} / \mathrm{ml}$ gentamicin. After $10 \mathrm{~d}$ of culture the astrocytes were separated from microglia and oligodendrocytes by shaking for $24 \mathrm{hr}$ in an orbital shaker at $240 \mathrm{rpm}$. The shaking was repeated twice after a gap of 1 or $2 \mathrm{~d}$ for the complete removal of all of the oligodendrocytes and microglia before subculturing. Cells were trypsinized and subcultured. C6 rat glioma cells (obtained from American Type Culture Collection, Manassas, VA) were maintained in DMEM containing $3 \mathrm{gm} / 1$ glucose, 10\% fetal bovine serum (FBS), and $10 \mu \mathrm{g} / \mathrm{ml}$ gentamicin. All of the cultured cells were maintained at $37^{\circ} \mathrm{C}$ in $5 \% \mathrm{CO}_{2} / 95 \%$ air. At $80 \%$ confluency the cells were incubated with serum-free DMEM medium for $24 \mathrm{hr}$ before incubation with LPS and other chemicals.

Assay for NO production and induction of iNOS enzyme. C6 rat glioma cells and astrocytes were cultured in 12-well plastic tissue culture plates. After the appropriate treatment the production of NO was determined by an assay of the culture supernatant for nitrite (Green et al., 1982). Briefly, $100 \mu \mathrm{l}$ of culture supernatant was allowed to react with $100 \mu \mathrm{l}$ of Griess reagent. The optical density of the assay samples was measured spectrophotometrically at $570 \mathrm{~nm}$. Nitrite concentrations were calculated from a standard curve derived from the reaction of $\mathrm{NaNO}_{2}$ in fresh media. For iNOS protein the cells were washed with cold Tris-buffered saline (TBS; $20 \mathrm{~mm}$ Trizma base and $137 \mathrm{~mm} \mathrm{NaCl}, \mathrm{pH}$ 7.5) and lysed in $1 \times$ SDS sample loading buffer ( $62.5 \mathrm{~mm}$ Trizma base, $2 \% \mathrm{w} / \mathrm{v}$ SDS, $10 \%$ glycerol); after sonication and centrifugation at $15,000 \times g$ for $5 \mathrm{~min}$, the supernatant was used for the iNOS Western immunoblot assay.

Western blot analysis. The protein concentration of samples was determined with the detergent-compatible protein assay reagent (Bio-Rad Laboratories, Hercules, CA) by using bovine serum albumin (BSA) as the standard. Samples were boiled for $3 \mathrm{~min}$ with 0.1 volume of $10 \%$ $\beta$-mercaptoethanol and $0.5 \%$ bromophenol blue mix. Then $50 \mu \mathrm{g}$ of total cellular protein and $10 \mu \mathrm{g}$ of nuclear extract or membrane protein or cytoplasmic protein were resolved by electrophoresis in 8 or $12 \%$ polyacrylamide gels, electrotransferred to polyvinylidene difluoride (PVDF) filter, and blocked with PVDF buffer [I-Block (Tropix, Bedford, MA), $10 \mathrm{~mm}$ Trizma base, $\mathrm{pH} 7.4,1 \%$ Tween 20, and $150 \mathrm{~mm} \mathrm{NaCl}$ ]. After incubation with antiserum against iNOS $(1: 1000 ; 610432, \mathrm{BD}$ PharMingen, San Diego, CA), hRas (1:1000; sc-520), RhoA (1:1000; sc$179)$, C/EBP- $\beta$ (1:1000; sc-150), C/EBP- $\delta$ (1:1000; sc-151), CHOP (1: 1000; GADD153, sc-575, all from Santa Cruz Biotechnology, Santa Cruz, Ca), or G6PD (1:500; G3053-05-1ml, United States Biological, Swampscott, MA) in PVDF buffer for $2 \mathrm{hr}$ at room temperature, the filters were washed three times with PVDF buffer and then incubated with goat anti-rabbit donkey IgG-horseradish peroxidase conjugate (1:5000) for 1 hr. The membranes were autoradiographed by using ECL Plus (Amersham Biosciences, Piscataway, NJ) after being washed with PVDF buffer.

Isolation of total RNA and Northern blot assay. C6 rat glioma cells were cultured in six-well plastic tissue culture plates. After the appropriate treatment the total cellular RNA was extracted by the use of a rapid guanidine thiocyanate water-saturated phenol/chloroform extraction procedure and by subsequent precipitation with acidic sodium acetate. Total RNA $(5 \mu \mathrm{g})$ was denatured and electrophoresed on $1 \%$ agaroseformaldehyde gels and transferred onto nylon Hybond-N hybridization membrane sheets (Amersham Biosciences). After UV cross-linking, the membranes were prehybridized at $68^{\circ} \mathrm{C}$ in prehybridization buffer $(5 \times$ SSC, $50 \%$ formamide, $0.02 \%$ SDS, $0.1 \%$ sodium $N$-lauroyl sarcosine, and $2 \%$ blocking reagent). The digoxigenin (DIG)-labeled iNOS probes were added to the prehybridization buffer and incubated overnight. The iNOS probe was generated by in vitro transcription from partial rat iNOS cDNA (1-893 bp), which was generated by reverse transcriptase-PCR, using primers ( $5^{\prime}$-ATG GCT TGC CCC TGG AAG TTT CTC T- $3^{\prime}$ and 5'-AGC GGC CAT AGC GGG GCT T-3') from total RNA from C6 rat glioma cells and subsequent cloning to an EcoRV site on pBluescript II $\mathrm{KS}^{+}$(Stratagene, La Jolla, CA). The membranes were washed three times in $2 \times$ SSC and $0.1 \%$ SDS at room temperature and in $0.1 \times$ SSC and $0.1 \%$ SDS at $68^{\circ} \mathrm{C}$. After the membranes were equilibrated in maleic acid buffer (100 mm maleic acid and $150 \mathrm{~mm} \mathrm{NaCl}, \mathrm{pH}$ 7.5), the membranes were blocked in maleic acid buffer containing $1 \%$ blocking reagent (Roche Molecular Biochemicals, Indianapolis, IN). The chemiluminescent autoradiography detection was performed as suggested by the manufacturer (Roche Molecular Biochemicals), using an alkaline phosphataseconjugated anti-DIG $\mathrm{F}_{\mathrm{ab}}$ fragment (Roche Molecular Biochemicals) and CSPD [disodium 3-(4-methoxyspiro \{1,2-dioxetane-3,2'-(5' -chloro) tricyclo $\left[3.3 .1 .1^{3,7}\right]$ decan $\}-4$-yl) phenyl phosphate (Roche Molecular Biochemicals)].

Nuclear extraction. Nuclear extracts from C6 cells and astrocytes $(1 \times$ $10^{7}$ cells) were prepared by using a previously published method (Dignam et al., 1983) with a slight modification. Cells were harvested, washed twice with ice-cold TBS, and lysed in $400 \mu \mathrm{l}$ of buffer A containing (in mM) $10 \mathrm{KCl}, 2 \mathrm{MgCl}_{2}$, and 0.5 dithiothreitol plus protease inhibitor mixture (Sigma, St. Louis, MO) and $0.1 \%$ Nonidet P-40 in $10 \mathrm{~mm}$ HEPES, pH 7.9, for 10 min on ice. After centrifugation at $1000 \times g$ the pelleted nuclei were washed with buffer A without Nonidet P-40 and resuspended in $40 \mu \mathrm{l}$ of buffer B containing $25 \%$ (v/v) glycerol, $0.42 \mathrm{M}$ $\mathrm{NaCl}$, plus (in mM) $1.5 \mathrm{MgCl}_{2}, 0.2$ EDTA, 0.5 dithiothreitol, and protease inhibitor mixture (Sigma) in $20 \mathrm{~mm}$ HEPES, pH 7.9, for $30 \mathrm{~min}$ on ice. The lysates were centrifuged at $15,000 \times g$ for $15 \mathrm{~min}$, and the supernatants containing the nuclear proteins were stored at $-70^{\circ} \mathrm{C}$ until use.

Extraction of membrane and cytoplasmic fraction. C6 rat glioma cells were cultured in $60 \mathrm{~mm}$ plastic tissue culture dishes. After the appropriate treatment the cells were washed with ice-cold PBS and collected by scraping. After centrifugation at $1500 \times g$ for 3 min the cells were subjected to sonication in (in mM) $10 \mathrm{HEPES}, \mathrm{pH} 7.9,10 \mathrm{KCl}, 2 \mathrm{MgCl}_{2}$, and 0.5 dithiothreitol plus protease inhibitor mixture (Sigma) and were centrifuged at $150,000 \times \mathrm{g}$ for $30 \mathrm{~min}$ at $4^{\circ} \mathrm{C}$. The pellet (membrane fraction) or supernatant (cytosolic fraction) was dissolved in $50 \mu \mathrm{l}$ of $1 \times$ or an equal volume of $2 \times$ SDS sample loading buffer $(0.125 \mathrm{~m}$ Trizma base, $4 \%$ w/v SDS, 20\% glycerol), respectively.

Gel shift assay (electrophoretic mobility shift assay). Nuclear proteins $(10 \mu \mathrm{g})$ were used for the electrophoretic mobility shift assay for the detection of AP-1, NF- $\kappa$ B, and C/EBP DNA binding activities. DNAprotein binding reactions were performed at room temperature for 20 min in (in mM) 10 Trizma base, $\mathrm{pH} 7.9,50 \mathrm{NaCl}, 5 \mathrm{MgCl}_{2}, 1$ EDTA, and 1 dithiothreitol plus $1 \mu \mathrm{g}$ of poly $(\mathrm{dI}-\mathrm{dC}), 5 \%(\mathrm{v} / \mathrm{v})$ glycerol, and $\sim 0.3$ pmol of AP-1 (Santa Cruz Biotechnology) or NF- $\kappa$ B (Santa Cruz Biotechnology) or C/EBP (Santa Cruz Biotechnology) labeled with DIG-11dideoxy UTP, using terminal deoxynucleotidyl transferase (Roche Molecular Biochemicals). Protein-DNA complexes were resolved from protein-free DNA in $5 \%$ polyacrylamide gels at room temperature in 50 mu Tris, pH 8.3, $0.38 \mathrm{~m}$ glycine, and 2 mM EDTA and were electroblotted onto positively charged nylon membranes. The chemiluminescence detection method for DIG-labeled probes was identical to the method used for the nonisotopic Northern blot analysis.

Knockdown of G6PD by using antisense DNA oligomer. For the transfection the C6 rat glioma cells were cultured on 24-well plates. At $80 \%$ of confluency the G6PD antisense DNA oligomer (5'-AAG-CCA-CCTGCT-CTG-CCA-TG-3'), which has an equivalent location to -1 to $\sim 19$ of rat G6PD cDNA sequence (Ho et al., 1988), and its sequencescrambled oligomer (5' -GCC-TAC-ATA-CGA-GCC-TTG-AC-3') were transfected by using Oligofectamin (Invitrogen, San Diego, CA) according to the manufacturer's instructions.

Plasmid constructs and site-directed mutagenesis. Expression vector coding wild-type mouse $\mathrm{C} / \mathrm{EBP}-\delta$ protein (pBluescript-MSV-C/EBP- $\delta$ ) was a gift from Steve L. McKnight (Tularik, South San Francisco, CA). The pGL3 (Promega, Madison, WI) containing $-3.2 \mathrm{~kb}$ of the $5^{\prime}$ flanking region of rat iNOS gene (pGL3/-3.2iNOS) was a gift of Dr. 
Hangfang Zhang (Zhang et al., 1998). The site-directed mutant pGL3/ $-3.2 \mathrm{iNOS} \Delta \mathrm{C} / \mathrm{EBP}-2$ was constructed by a megaprimer method (Barik, 1996). Briefly, in the first PCR the mutant primer ( $5^{\prime}$-GAT ACA CCA CAG AGT GAC TTT ATA ATG CAT ACA GAC TAG G-3'), which was mutated from wild-type C/EBP-2 sequence $\left(-1715^{\prime}\right.$-T GAC GTA AT-3' -163 ) and $3^{\prime}$-terminal primer (5'-CTT AGA TCG CAG ATC TCG AG$3^{\prime}$ ), and SacI-digested wild-type pGL3/-3.2iNOS as a template were used. The double-stranded product was used in the second PCR with the 5'-terminal primer ( $5^{\prime}$-ACG CGT GGT CGA CGG CCC GGG-3'). After PCR the product was resolved in $0.8 \%$ agarose gel and extracted by Qiaquick gel extraction kit (Qiagen, Chatsworth, CA). The purified PCR product and pGL3-basic were restricted with MluI and XhoI and ligated. Correct mutagenesis was confirmed finally by sequencing.

Transient transfections and reporter gene assay. C6 rat glioma cells $(3 \times$ $10^{5}$ cells/well) were cultured in six-well plates for $36 \mathrm{hr}$ before transfection. Transfection was performed with $2 \mu \mathrm{g}$ of reporter gene (pGL3/ $-3.2 \mathrm{iNOS}$ or $\mathrm{pGL} 3 /-3.2 \mathrm{iNOS} \Delta \mathrm{C} / \mathrm{EBP}-2)$ and $0.5 \mu \mathrm{g}$ of pCMV- $\beta$-gal and $8 \mu \mathrm{l}$ of Fugene transfection reagent (Roche Molecular Biochemicals). For the cotransfection assay $1.8 \mu \mathrm{g}$ of pBluescript-MSV-C/EBP- $\delta$ or pBluescript $\mathrm{KS}^{+}$(Stratagene) and $0.6 \mu \mathrm{g}$ of pGL3/-3.2iNOS or pGL3/ $-3.2 \mathrm{iNOS} \Delta \mathrm{C} / \mathrm{EBP}-2$ and $0.2 \mu \mathrm{g}$ of pCMV- $\beta$-gal were used. At $1 \mathrm{~d}$ after transfection the cells were placed in serum-free media overnight. After appropriate treatment the cells were washed with PBS, scraped, and then resuspended with $100 \mu \mathrm{l}$ of lysis buffer [containing (in mM) 40 Tricine, $\mathrm{pH} 7.8,50 \mathrm{NaCl}, 2$ EDTA, $1 \mathrm{MgSO}_{4}$, and 5 dithiothreitol plus $1 \%$ of Triton X-100]. After incubation at room temperature for $15 \mathrm{~min}$ with occasional vortexing, the samples were centrifuged. The luciferase and $\beta$-galactosidase activities were measured by using a luciferase assay kit (Stratagene) and $\beta$-gal assay kit (Invitrogen), respectively. The emitted light and optical absorbance was measured by using SpectraMax/Gemini XG (Molecular Devices, Sunnyvale, CA) and SpectraMax 190 (Molecular Devices), respectively.

Biochemical assay. NADPH and $\mathrm{NADP}^{+}$were measured as described previously (Zhang et al. 2000). In brief, the absorbance at $340 \mathrm{~nm}$ of these separate fractions (A1, A2, and A3) was measured. A1 was the untreated cell extract. A2 was the cell extract treated with a glucose-6-phosphate dehydrogenase (G6PD) and glucose-6-phosphate to convert all of the $\mathrm{NADP}^{+}$to NADPH; then the absorbance was measured. A3 was the cell extract treated with a glutathione reductase and oxidized glutathione to convert all of the NADPH to $\mathrm{NADP}^{+}$; then the absorbance was measured. Absorbance A1 - A3 was reflective of NADPH content, and absorbance $\mathrm{A} 2-\mathrm{A} 1$ was reflective of $\mathrm{NADP}^{+}$content of the extract.

For the quantification of intracellular ATP level, C6 cells were plated in 12-well plastic plates. After appropriate treatment the cells were washed with cold PBS and then treated with boiling $200 \mu \mathrm{l}$ of $100 \mathrm{~mm}$ Tris, $\mathrm{pH}$ 7.75 , and $4 \mathrm{~mm}$ EDTA and further boiled for $2 \mathrm{~min}$. After centrifugation at $1000 \times g$ for $60 \mathrm{sec}$ the ATP levels of the supernatant were measured by an ATP bioluminescence assay kit (Roche Molecular Biochemicals) according to the manufacturer's instruction.

For the quantification of lactate dehydrogenase (LDH) release the C6 cells were plated in 12-well plastic plates. After appropriate treatment the medium was collected in a $1.5 \mathrm{ml}$ microcentrifuge tube. After centrifugation at $250 \times g$ the LDH activity was measured by using an $\mathrm{LDH}$ activity detection kit (Roche Molecular Biochemicals).

For the cell viability assay, $1 / 20$ volume of MTT reagent $(5 \mathrm{mg} / \mathrm{ml}$; Sigma) was added to cell media. At $2 \mathrm{hr}$ after the incubation the cells were washed with PBS and dissolved in isopropanol, including $0.1 \mathrm{~N} \mathrm{HCl}$. The cell viability was measured at an optical density of $570 \mathrm{~nm}$ by SpectraMax 190 (Molecular Devices).

For the measurement of cellular glutathione the cells $\left(3 \times 10^{6}\right)$ were pelleted and resuspended in 5\% metaphosphoric acid. After homogenization by Teflon pestle the lysate was centrifuged at $3000 \times g$ for $10 \mathrm{~min}$. The glutathione level in the supernatant was measured by a kit provided by Calbiochem (La Jolla, CA).

Statistical analysis. All values shown in the figures are expressed as the means \pm SEM of $n$ determinations, obtained from at least three independent experiments. The results were examined by one- and two-way ANOVA; then individual group means were compared with the Bonferroni test. A $p$ value $<0.05$ was considered significant.

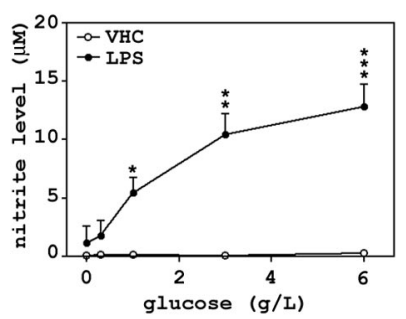

Figure 1. Extracellular glucose regulates the LPS-induced iNOS gene expression and NO production in (6 rat glioma cells. Effect of glucose $(0,0.3,1,3$, and $6 \mathrm{gm} / \mathrm{l})$ on the induction of iNOS mRNA and on protein and NO production was examined after $6 \mathrm{hr}$ (for iNOS mRNA level) or $24 \mathrm{hr}$ (for iNOS protein and NO levels) of LPS $(2 \mu \mathrm{g} / \mathrm{ml})$ treatment. The cells were pretreated for $36 \mathrm{hr}$ before LPS treatment. The nitrite level was normalized with total protein quantity. The $28 \mathrm{~S}$ rRNA was used as an internal loading standard in Northern blot analysis. The procedures for measurement of RNA and of protein and N0 are described in Materials and Methods. The error bars indicate the SEM $\left({ }^{*} p<0.05,{ }^{* *} p<0.01\right.$, and ${ }^{* * *} p<0.001$ as compared with $0 \mathrm{gm} / \mathrm{l}$ of the glucose-treated group).
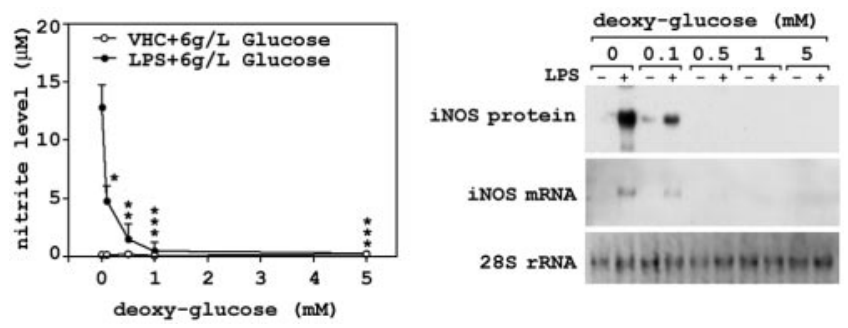

Figure 2. The effect of 2-deoxy-D-glucose on LPS-induced NO production and iNOS gene expression in C6 rat glioma cells. At $6 \mathrm{hr}$ (for iNOS mRNA level) or $24 \mathrm{hr}$ (for iNOS protein and NO levels) after LPS (2 $\mu \mathrm{g} / \mathrm{ml})$ stimulation the effects of indexed concentrations of 2-deoxy-Dglucose (deoxy-glucose; $0,0.1,0.5,1$, and $5 \mathrm{~mm}$ ) on the levels of iNOS mRNA and of protein and nitrite were examined. The cells were pretreated with deoxy-glucose for $36 \mathrm{hr}$ before LPS (2 $\mu \mathrm{g} / \mathrm{ml})$ treatment in the presence of $6 \mathrm{gm} / \mathrm{l}$ glucose. The nitrite level was normalized with total protein quantity. Levels of $28 \mathrm{~S}$ rRNA were used as an internal standard in Northern blot analysis. The error bar at each time indicates the SEM $\left({ }^{*} p<0.05,{ }^{* *} p<0.01\right.$, and ${ }^{* * *} p<0.001$ as compared with $0 \mathrm{gm} / \mathrm{l}$ of the glucose-treated group).

\section{Results}

\section{The extracellular glucose regulates LPS-induced NO} production and iNOS gene expression

Previous studies report the role of insulin (Zhu and Auer, 1994) and peripheral glucose concentration (Hamilton et al., 1995) in the pathophysiology of ischemia reperfusion insult. In the present study we tested whether insulin/IGFs or extracellular glucose concentration regulated iNOS gene expression. Pretreatment with various doses of insulin, IGF-1, or IGF-2 failed to regulate the LPS-induced iNOS gene expression (data not shown). On the other hand, cells pretreated with glucose $(0,1,3$, and $6 \mathrm{gm} / \mathrm{l}$ ) for $36 \mathrm{hr}$ before treatment with LPS enhanced the induction of mRNA and protein levels of iNOS and production of NO in a dose-dependent manner (Fig. 1). In the absence of LPS the glucose was not able to induce the expression of iNOS gene. To prove the involvement of metabolic activity of glucose in the regulation of iNOS gene induction, we pretreated the cells with various concentrations $(0,0.05,0.1,0.5$, and $1 \mathrm{~mm})$ of 2-deoxyD-glucose (a metabolic inhibitor of glucose metabolism via saturating hexokinase) in the presence of $6 \mathrm{gm} / \mathrm{l}(33.3 \mathrm{~mm})$ of glucose for $36 \mathrm{hr}$ before the incubation with LPS. 2-Deoxy-D-glucose inhibited the LPS-induced NO production and iNOS protein and its mRNA levels in a concentration-dependent manner (Fig. 2). These studies indicate that a metabolite of the glucose oxidation pathway may play a role in the regulation of LPS-mediated induction of iNOS gene. 
A

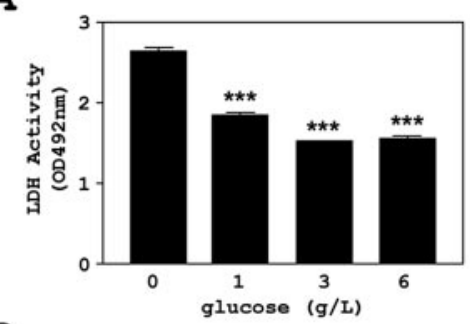

B
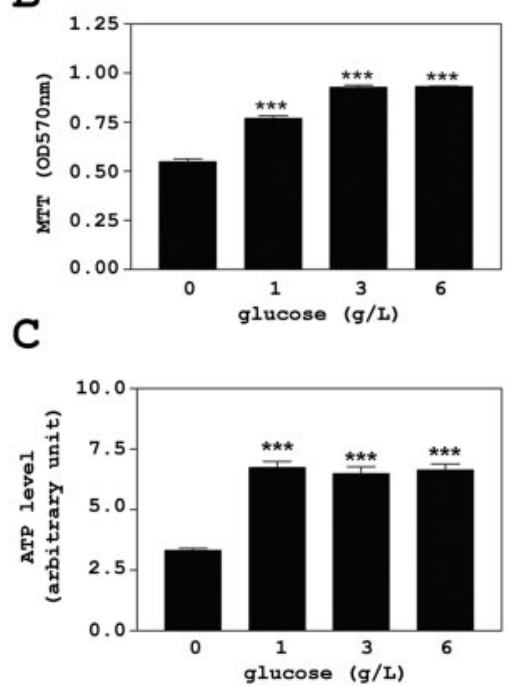

Figure 3. The effect of extracellular glucose concentration on cytotoxicity/viability of 66 rat glioma cells. (6 rat glioma cells were incubated with indexed concentrations of glucose $(0,1,3$, and $6 \mathrm{gm} / \mathrm{l}$ ) for $36 \mathrm{hr}$. Lactate dehydrogenase (LDH) in medium ( $A$ ), cell viability (MTT assay; $B$ ), and intracellular ATP level $(C)$ were examined as described in Materials and Methods. The LDH activity and ATP level were normalized with total protein quantity. The error bars in each panel indicate the SEM $\left({ }^{*} p<0.05,{ }^{* *} p<0.01\right.$, and ${ }^{* * *} p<0.001$ as compared with $0 \mathrm{gm} / \mathrm{l}$ of the glucose-treated group).

The effect of extracellular glucose concentration on cell toxicity, viability, and intracellular ATP level

To investigate the possible involvement of cell toxicity or viability evoked by glucose availability in the regulation of iNOS gene expression, we performed the LDH assay and microculture tetrazolium colorimetric (MTT) assay after $36 \mathrm{hr}$ of incubation with various concentrations of glucose (Fig. $3 A, B$ ). In glucose-starved conditions the $\mathrm{C} 6$ cells released the highest levels of LDH to media and showed the lowest cell viability (optical density of MTT). Although the addition of glucose reduced LDH release and increased cell viability up to $3 \mathrm{gm} / \mathrm{l}$ glucose, there was no significant difference between 3 and 6 $\mathrm{gm} / \mathrm{l}$ of the glucose-treated groups. Because glucose is the major source for ATP generation in brain cells, the effect of extracellular glucose concentration on intracellular ATP level was examined after $36 \mathrm{hr}$ of incubation with indexed glucose concentrations (Fig. $3 \mathrm{C}$ ). In the glucose-starved group the intracellular ATP level was lowest. The addition of glucose increased the intracellular ATP level, but there was no significant difference among 1, 3, and $6 \mathrm{gm} / 1$ of the glucose-treated groups. These observations indicate that the intracellular level of ATP does not correlate with the enhancement of LPSmediated induction of iNOS; therefore, it may not be responsible for glucose-mediated upregulation of iNOS.
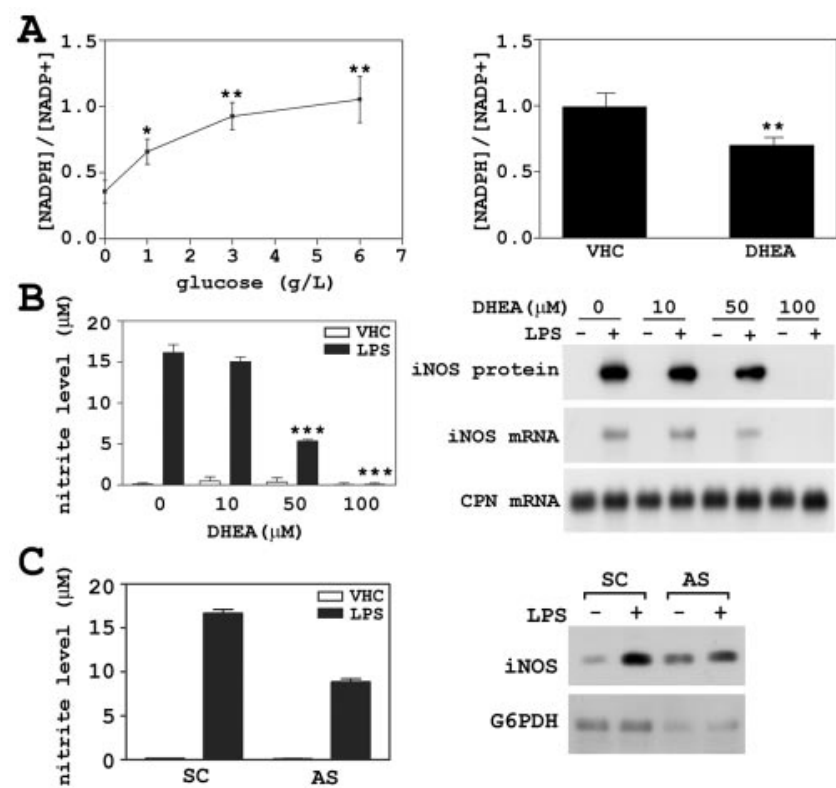

Figure 4. The effect of extracellular glucose concentration on the intracellular NADPH/ $\mathrm{NADP}^{+}$ratio and the possible role of G6PD in glucose-mediated upregulation of LPS-induced iNOS gene expression in 6 rat glioma cells. The C 6 cells were treated with various glucose concentrations $(0,1,3$, and $6 \mathrm{gm} / \mathrm{l})$ for $36 \mathrm{hr}$ or DHEA (100 $\mu \mathrm{M})$ plus $6 \mathrm{gm} / \mathrm{I} \mathrm{glucose} \mathrm{for} 0.5 \mathrm{hr}$ before treatment with LPS $(2 \mu \mathrm{g} / \mathrm{ml})$ and then were harvested for measurement of NADPH and $\mathrm{NADP}^{+}$levels as described in Materials and Methods $(A)$. Each concentration of NADPH and $\mathrm{NADP}^{+}$was normalized with total protein quantity. The effect of indexed concentrations of $\operatorname{DHEA}(0,10,50$, and $100 \mu \mathrm{M})$ on nitrite production and on iNOS protein and its mRNA levels was examined in the presence or absence of LPS $(B)$. The iNOS mRNA levels were measured after $6 \mathrm{hr}$ of LPS treatment. Nitrite and iNOS protein were measured after $24 \mathrm{hr}$ of LPS treatment. Cyclophilin (CPN) was used as an internal standard in Northern blot analysis. For the knockdown of G6PD the cells were transfected with glucose 6-phosphate dehydrogenase (G6PD) antisense DNA oligomer or its sequence-scrambled DNA oligomer as described in Materials and Methods (C). At $2 \mathrm{~d}$ after transfection the cells were stimulated with LPS, and N0 production and the protein levels of iNOS and G6PD were measured. The error bars in each panel indicate the SEM ${ }^{*} p<0.05,{ }^{* *} p<0.01$, and ${ }^{* * *} p<0.001$ as compared with $0 \mathrm{gm} / \mathrm{l}$ of the glucose-treated group).

The effect of extracellular glucose concentration on the intracellular NADPH/NADP ${ }^{+}$ratio and the possible involvement of G6PD in glucose-dependent enhancement of LPS-induced iNOS gene expression

Another metabolic pathway of glucose is the pentose phosphate pathway (PPP). The importance of PPP lies in the production of ribose and NADPH. To investigate the possible role of PPP on the induction of iNOS, we examined the effect of dehydroepiandrosterone (DHEA), an inhibitor of G6PD (rate-limiting enzyme in $\mathrm{PPP}$ ), on glucose-mediated change in the ratio of NADPH/ $\mathrm{NADP}^{+}$and induction of iNOS. As shown in Figure $4 A$, the extracellular glucose increased the intracellular NADPH/ $\mathrm{NADP}^{+}$ratio in a dose-dependent manner. In addition, the high glucose-induced $(6 \mathrm{gm} / \mathrm{l})$ increase of $\mathrm{NADPH} / \mathrm{NADP}^{+}$ratio was reduced significantly by pretreatment of the cells with DHEA. The pretreatment with DHEA also decreased the LPS-induced NO production and iNOS gene expression in a dose-dependent manner in the presence of $6 \mathrm{gm} / \mathrm{lglucose}$ (Fig. 4). To confirm the role of G6PD in iNOS gene regulation, we incubated the cells with antisense DNA oligomer against rat G6PD mRNA and sequencescrambled DNA oligomer as a control before treatment with LPS. As shown Figure $4 C$, antisense DNA oligomer reduced significantly the LPS-mediated increases in NO production and iNOS protein level as well as G6PD protein levels. This result further supported the involvement of G6PD in iNOS gene regulation. 
A
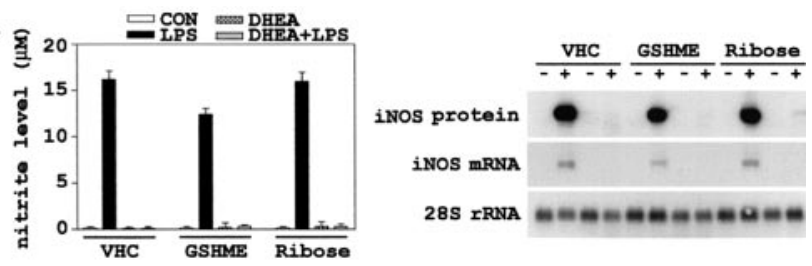

B

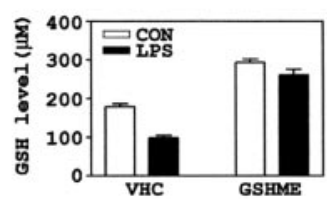

Figure 5. The effect of glutathione monoethylester and ribose on DHEA-mediated inhibition of iNOS gene expression in (6 rat glioma cells. After incubation of cells with glutathione monoethylester (GSHME; $500 \mu \mathrm{m}$ ) or ribose $(5 \mathrm{~mm})$ for $0.5 \mathrm{hr}$, the cells were treated with vehicle (VHC; dimethylsulfoxide) or dehydroepiandrosterone (DHEA; $100 \mathrm{M}$ ) for $0.5 \mathrm{hr}$ and then with LPS (2 $\mu \mathrm{g} / \mathrm{ml} ; A)$. The iNOS mRNA level and its protein and nitrite levels were measured after LPS treatment for 6 or $24 \mathrm{hr}$, respectively. Cyclophilin (CPN) was used as an internal loading standard in Northern blot analysis. To examine the cellular glutathione (GSH) level, we pretreated the cells with GSHME $(500 \mu \mathrm{m}) 0.5 \mathrm{hr}$ before DHEA treatment $(B)$. At $4 \mathrm{hr}$ after DHEA treatment the cellular GSH levels were measured as described in Materials and Methods. The error bars in $A$ and $B$ indicate the SEM.

The major known function of PPP is the generation of ribose and reduced glutathione. As shown in Figure 5A, the pretreatment with ribose $(5 \mathrm{mM})$ or glutathione monoethylester (GSHME; $500 \mu \mathrm{M}$ ), a cell-permeable analog of glutathione, had no effect on DHEA-evoked inhibition of iNOS gene expression and production of NO by LPS. To examine the effect of DHEA and GSHME on cellular glutathione level, we measured the intracellular glutathione level $4 \mathrm{hr}$ after DHEA treatment. As shown in Figure $5 B$, the cellular glutathione level was reduced by the treatment with DHEA, whereas it increased by GSHME. These observations further support that ribose or glutathione was not involved in glucose-mediated induction of iNOS.

\section{Activation of small GTPase is not involved in extracellular} glucose-mediated regulation of iNOS gene expression

Because the reduction of acetyl-CoA and NADPH can evoke a subsequent reduction of protein isoprenylation by attenuation of intracellular levels of mevalonic acid, the effect of extracellular glucose concentration on membrane association of small GTPase was examined. As shown in Figure 6, $A$ and $B$, various concentrations of glucose had no effect on the translocation of hRas and RhoA proteins to the membrane. Moreover, pretreatment with various concentrations of farnesyl pyrophosphate (FPP; 1,5 , and $10 \mu \mathrm{M}$ ) or geranylgeranyl pyrophosphate (GGPP; 1,5 , and 10 $\mu \mathrm{M})$, ligands required for the translocation of small GTPase to plasma membrane, did not reverse the glucose starvation-evoked inhibition of LPS-induced NO production. To confirm the uninvolvement of farnesylation or geranyl-geranylation of hRas or RhoA protein in glucose-dependent NO production, we also examined the effect of lovastatin, an inhibitor of 3-hydroxy-3methylglutaryl coenzyme A reductase that in turn blocks the de novo synthesis of farnesyl pyrophosphate and geranylgeranyl pyrophosphate, on LPS-induced NO production. Rather than inhibition, the pretreatment with lovastatin resulted in the enhancement of LPS-mediated NO production in the presence of $6 \mathrm{gm} / 1$ glucose (Fig. $6 \mathrm{C}$ ). These observations indicate that the state of farnesylation or geranyl-geranylation of small GTPase is not responsible for glucose-mediated LPS-induced expression of iNOS and NO production.
A

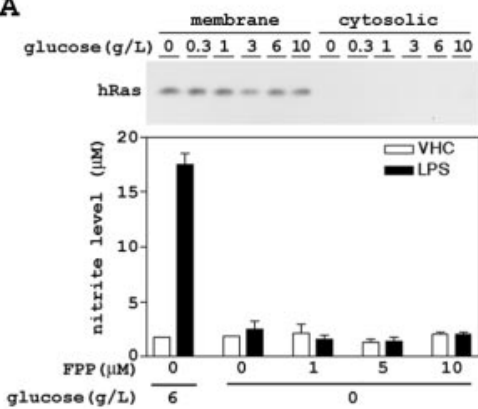

B

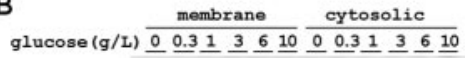
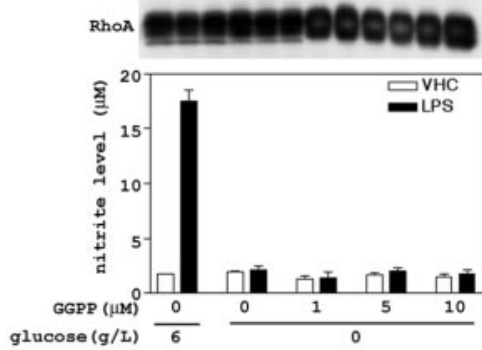

C

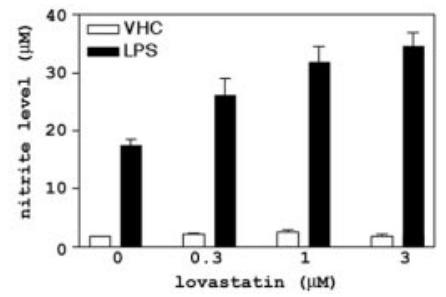

Figure 6. The uninvolvement of small GTPase in glucose-mediated regulation of NO production in $C 6$ rat glioma cells. The effect of glucose on the distribution of protein levels of $h$ Ras $(A)$ or RhoA $(B)$ between plasma membrane or cytoplasmic fraction was examined (top panels). After treatment with indexed concentrations of glucose $(0,0.3,1,3$, and $6 \mathrm{gm} / \mathrm{l})$ for $36 \mathrm{hr}$ the cells were fractionated into membrane or cytoplasmic proteins and analyzed by Western blot analysis. The bottom panels of $A$ and $B$ show the effect of farnesyl pyrophosphate (FPP; $0,1,5$, and $10 \mu \mathrm{M}$ ) or geranylgeranyl pyrophosphate (GGPP; $0,1,5$, and $10 \mu \mathrm{m}$ ) on the glucosemediated production of nitrite in the presence or absence of LPS $(2 \mu \mathrm{g} / \mathrm{ml})$. C, The effect of various concentrations of lovastatin $(0,0.3,1$, and $3 \mu \mathrm{m})$ on LPS-induced nitrite production was examined in the presence of $6 \mathrm{gm} / \mathrm{I}$ glucose supplement. The nitrite levels were determined 24 hr after LPS treatment. The error bars in each panel indicate the SEM.

The effect of extracellular glucose concentration and DHEA on the NF- $\kappa \mathrm{B}, \mathrm{AP}-1$, and $\mathrm{C} / \mathrm{EBP}$ activation

To understand the mechanism of glucose-mediated induction of iNOS, we examined the effects of glucose and DHEA on LPSinduced DNA binding activity of AP-1, NF- $\kappa \mathrm{B}$, and C/EBP response element by gel shift analysis. Cells were pretreated with several concentrations of glucose $(0,1,3$, and $6 \mathrm{gm} / \mathrm{l})$ for $36 \mathrm{hr}$ or DHEA $(0,10,50$, and $100 \mu \mathrm{M})$ for $0.5 \mathrm{hr}$ before the incubation with LPS (Fig. $7 A, B$ ). Although the AP-1 or NF- $\kappa$ B DNA binding activities and NF- $\kappa$ B transactivity (data not shown) induced by LPS were reduced partially in the glucose-free and $100 \mu \mathrm{M}$ DHEA-treated groups, there was no difference in AP- 1 or NF- $\kappa \mathrm{B}$ DNA binding activity induced by LPS in 1,3 , and $6 \mathrm{gm} / \mathrm{l}$ glucose or 10 and $50 \mu \mathrm{M}$ concentrations of the DHEA-treated group. However, C/EBP DNA binding activity correlated well with the iNOS gene expression (Fig. 7C). In the glucose-free condition C/EBP DNA binding activity was undetectable, but it was increased by the addition of glucose in a concentration-dependent manner. On the other hand, the increase of C/EBP DNA binding 

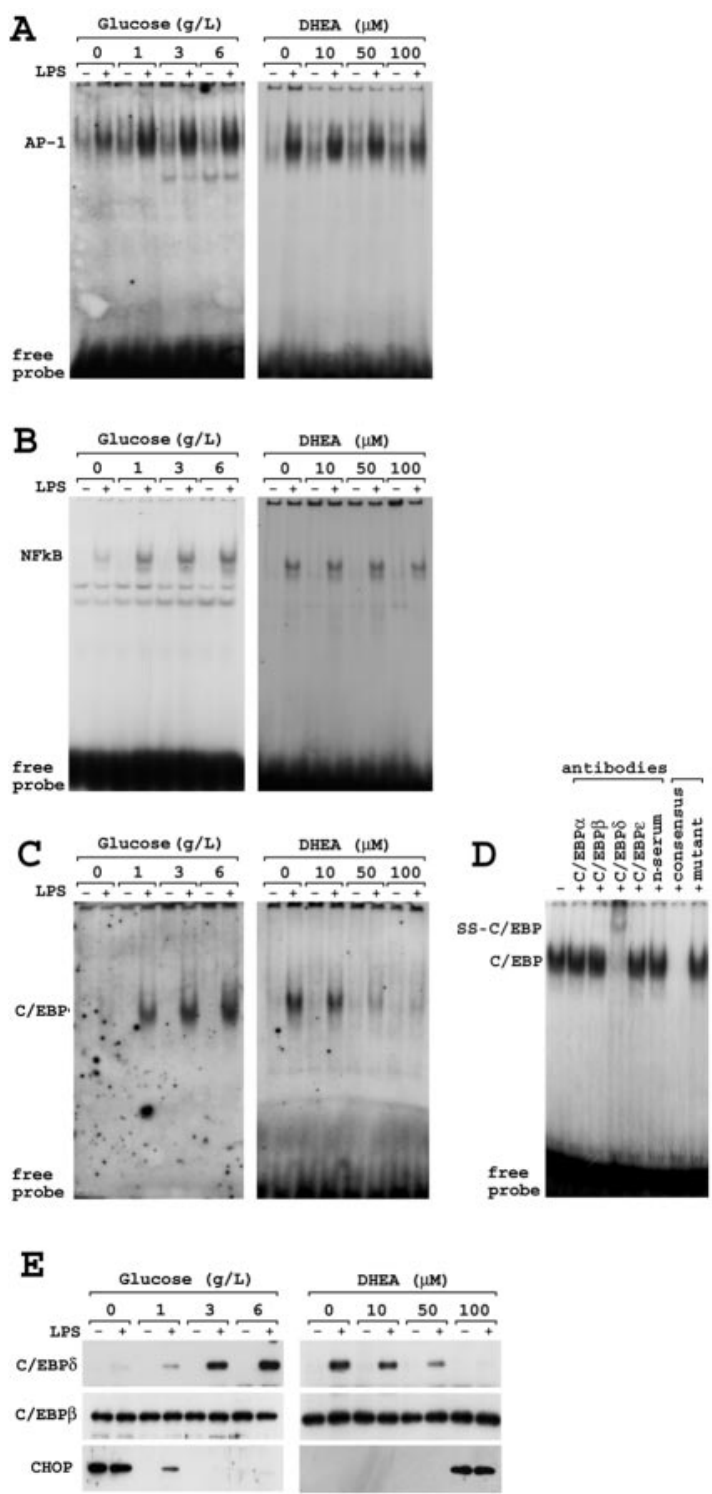

Figure 7. The effect of extracellular glucose concentration and DHEA on the activation of NF- $\kappa B$, AP- 1 , and $C / E B P$. The effects of glucose $(0,1,3$, and $6 \mathrm{gm} / \mathrm{I})$ and DHEA $(0,10,50$, and 100 $\mu \mathrm{M})$ on LPS-induced ( $2 \mu \mathrm{g} / \mathrm{ml})$ DNA binding activity of AP-1 $(A), \mathrm{NF}-\kappa B(B)$, and C/EBP (C) response element were examined by gel shift analysis as described in Materials and Methods. The cells were pretreated with glucose or DHEA for 36 or $0.5 \mathrm{hr}$, respectively. DHEA treatment was done after $36 \mathrm{hr}$ of incubation of the cells in $6 \mathrm{gm} / \mathrm{I}$ glucose-containing media. After 0.5 or $3 \mathrm{hr}$ the nuclear proteins were extracted for the gel shift assay of AP- 1 and C/EBP or NF- $\kappa$ B, respectively. For competition assay of $C / E B P$ response element binding activity $(D), 50 \times$ unlabeled consensus or mutant DNA oligomer was coincubated. For the supershift (ss) assay, $2 \mu \mathrm{g}$ of antibodies against C/EBP- $\alpha,-\beta,-\delta,-\epsilon$, or rabbit normal serum (n-serum) was preincubated with nuclear extract for $1 \mathrm{hr}$ before the addition of DNA probes (D). Nuclear proteins $(10 \mu \mathrm{g})$ from the experiments in C were used for Western blot analysis of C/EBP proteins $(E)$.

activity by LPS and $6 \mathrm{gm} / \mathrm{l}$ glucose was decreased by pretreatment with DHEA in a dose-dependent manner. The diminished C/EBP DNA binding activity in the presence of unlabeled selfcompetitor and lack of effect of mutant competitor suggest that the C/EBP DNA binding activity was specific (Fig. 7D). In the supershift assay only an antibody against C/EBP- $\delta$ could supershift C/EBP DNA binding activity induced by LPS and glucose. However, the antibodies against other $\mathrm{C} / \mathrm{EBP}(\alpha, \beta$, or $\epsilon$ forms) had no effect on LPS-induced C/EBP DNA binding activity. As shown in Figure $7 E$, C/EBP- $\delta$ protein was increased by extracel-
A
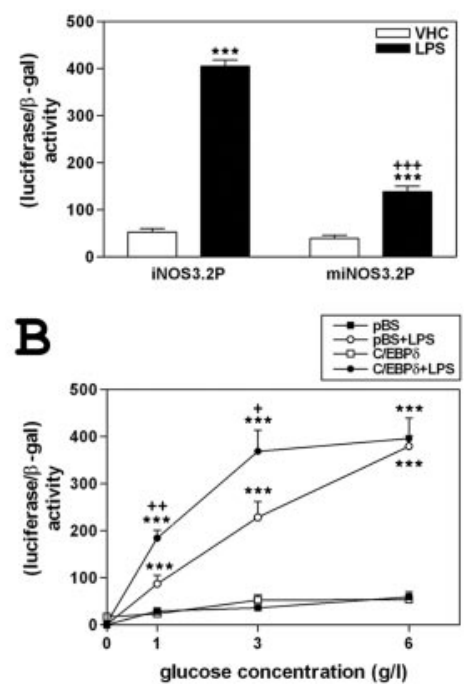

Figure 8. The involvement of C/EBP response element in iNOS promoter and C/EBP- $\delta$ in glucose-mediated iNOS expression. The promoter activity of luciferase-linked wild-type -3.2 $\mathrm{kb}$ of the $5^{\prime}$-flanking region of rat iNOS gene (iNOS3.2P) and its mutant form (miNOS3.2P), which contain the unfunctional C/EBP-2 response element sequence $(-171$ to approximately $-163)$, was examined in the presence or absence of LPS $(2 \mu \mathrm{g} / \mathrm{ml} ; A)$. The effect of C/EBP- $\delta$ overexpression on glucose-dependent regulation of iNOS promoter activity was examined in the presence or absence of LPS. After cotransfection with pBluescript KS ${ }^{-}$(pBS) or wild-type C/EBP- $\delta$ expression vector (C/EBP- $\delta$ ) and wild-type $-3.2 \mathrm{~kb}$ of the $5^{\prime}$-flanking region of rat iNOS gene, the cells were incubated further in various concentrations of glucose $(0,1,3$, or 6 $\mathrm{gm} / \mathrm{ll}$ ) for $36 \mathrm{hr}$ before treatment with LPS ( $B)$. The luciferase activity in this experiment was normalized with the enzyme activity of cotransfected $\beta$-galactosidase ( $\beta$-gal).

lular glucose in the presence of LPS in a dose-dependent manner, whereas C/EBP- $\beta$ was expressed constitutively and its expression was not affected by LPS or glucose. The C/EBP homologous protein (CHOP; also known as GADD153) was expressed only in glucose-free or $100 \mu \mathrm{M}$ DHEA-treated groups in the presence or absence of LPS. However, the increases in other C/EBP protein ( $\alpha, \gamma, \epsilon$ forms) levels were not detected in the presence or absence of LPS (data not shown). These observations indicate that $\mathrm{C} / \mathrm{EBP}-\delta$ may be one of the transcription factors sensing the extracellular glucose concentration under inflammatory conditions.

\section{The involvement of C/EBP response element in iNOS promoter and $\mathrm{C} / \mathrm{EBP}-\delta$ protein in glucose-dependent iNOS expression}

To elucidate the involvement of $\mathrm{C} / \mathrm{EBP}$ response element in iNOS gene expression, we examined the activity of wild-type $-3.2 \mathrm{~kb}$ iNOS gene promoter/enhancer (pGL3/-3.2iNOS) and its mutant form (pGL3/-3.2iNOS $\Delta$ C/EBP-2), which contained a nonfunctional $\mathrm{C} / \mathrm{EBP}-2$ response element sequence $(-171$ to approximately -163), in the presence or absence of LPS. As shown in Figure $8 A$, LPS induced the luciferase activity of pGL3/ $-3.2 \mathrm{iNOS}$ in the presence of $6 \mathrm{gm} / \mathrm{l}$ glucose, and it was reduced as much as $65 \%$ by the mutation of C/EBP-2 site on iNOS promoter (Fig. $8 A$ ). Figure $8 B$ shows the effect of $\mathrm{C} / \mathrm{EBP}-\delta$ overexpression on glucose-dependent regulation of iNOS promoter activity. After cotransfection with wild-type $\mathrm{C} / \mathrm{EBP}$ - $\delta$-overexpressing vector or pBluescript $\mathrm{KS}^{-}$(pBS) as its vehicle vector and pGL3/ $-3.2 \mathrm{iNOS}$, the cells were incubated in various concentrations of glucose in the presence or absence of LPS. In the cells transfected with vehicle vector, the extracellular glucose dose-dependently increased the activity of iNOS promoter in the presence of LPS 
A
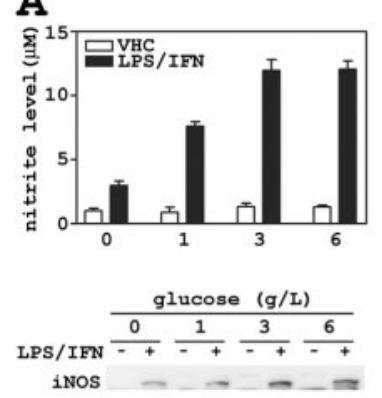

B
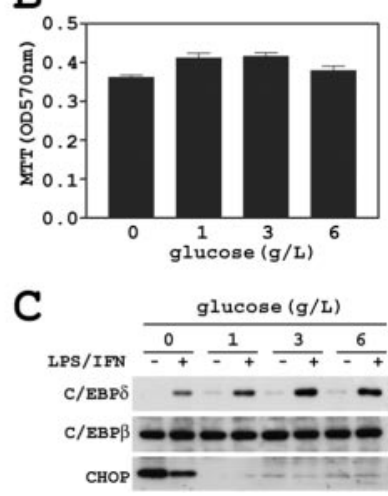

Figure 9. Extracellular glucose regulates the LPS-induced iNOS gene expression and NO production in primary cultured rat astrocytes. The effects of glucose $(0,1,3$, and $6 \mathrm{gm} / \mathrm{I})$ on the induction of NO production and iNOS protein level $(A)$ and the protein levels of C/EBP- $\beta$, C/EBP- $\delta$, and CHOP (C) were examined after $24 \mathrm{hr}$ (for NO production and iNOS protein) or $2 \mathrm{hr}$ (for C/EBP- $\delta$ protein) of LPS $(2 \mu \mathrm{g} / \mathrm{ml})$ and interferon- $\gamma(20 \mathrm{U})$ treatment. The pretreatment with glucose was done $36 \mathrm{hr}$ before the LPS and interferon- $\gamma$ treatments. The effect of various concentrations of glucose on cell viability was examined by MTT assay as described in Materials and Methods ( $B)$. The error bars in $A$ and $B$ indicate the SEM.

(Fig. $8 B$ ). Although the C/EBP- $\delta$ overexpression did not alter LPS-induced iNOS promoter activity in the absence of glucose, it significantly enhanced LPS-mediated induction of iNOS promoter activity in the presence of 1 and $3 \mathrm{gm} / \mathrm{l}$ glucose as compared with the vehicle vector-transfected group. These observations document that the signal(s) for upregulation of LPS-induced expression of iNOS by glucose may be mediated via upregulation of expression of $\mathrm{C} / \mathrm{EBP}-\delta$.

\section{Extracellular glucose regulates LPS-induced expression of iNOS and C/EBP- $\delta$ proteins in primary cultured rat astrocytes}

To compare the role of glucose in iNOS gene expression in C6 rat glioma cells and primary cultured astrocytes, we pretreated the astrocytes with several concentrations of glucose $(0,1,3$, and 6 $\mathrm{gm} / \mathrm{l})$ for $36 \mathrm{hr}$ before treatment with LPS. NO production, iNOS protein level, and C/EBP- $\beta$ and $\mathrm{C} / \mathrm{EBP}-\delta$ and $\mathrm{CHOP}$ protein levels were measured after the incubation of astrocytes with LPS and interferon- $\gamma$, as described in the legend to Figure 9. As shown in Figure 9, $A$ and $C$, the extracellular glucose enhanced the LPSmediated induction of NO production and iNOS and C/EBP- $\delta$ protein levels in a dose-dependent manner up to $3 \mathrm{gm} / \mathrm{l}$ glucose without altering the $\mathrm{C} / \mathrm{EBP}-\beta$ protein level. Additionally, $\mathrm{CHOP}$ was expressed only in a glucose-free condition like the C6 glioma cells. However, contrary to C6 rat glioma cells, there was no difference between 3 and $6 \mathrm{gm} / \mathrm{l}$ glucose. To examine the effect of glucose on cell viability, we performed an MTT assay after $36 \mathrm{hr}$ of treatment with glucose. Similar to C6 rat glioma cells, the glucose-free condition significantly reduced cell viability as compared with the 1 and $3 \mathrm{gm} / \mathrm{l}$ glucose conditions. Furthermore, we found that a high glucose condition also slightly reduced cell viability (Fig. 9B).

\section{Discussion}

Recent studies have suggested that insulin has a protective role in global and focal ischemia (Voll and Auer, 1988; Hamilton et al., 1995). Although the exact mechanism is not known, the animal data indicate that insulin may provide protection by direct interaction with IGF-1 receptor and/or an indirect action by reducing the blood glucose levels. Although NO produced by iNOS is be-

lieved to play a role in the pathophysiology of cerebral ischemic injury (Iadecola et al., 1997; Nagayama et al., 1998; Iadecola, 1999; O’Mahony and Kendall, 1999; Parmentier et al., 1999), little information is available about the possible regulation of iNOS gene expression by glucose. This study reports that signals for upregulation of the LPS-induced expression of iNOS by glucose were mediated via $\mathrm{C} / \mathrm{EBP}-\delta$. These conclusions are based on the following findings. (1) Extracellular glucose upregulated the expression of iNOS, whereas deoxyglucose blocked the induction of iNOS expression. (2) DHEA, an inhibitor of G6PD, or antisense DNA oligomer of G6PD mRNA blocked the induction of iNOS, indicating the possible role of PPP in the regulation of induction of iNOS. (3) The activation of C/EBP- $\delta$ by glucose and inhibition by DHEA paralleled the expression of iNOS. (4) The mutation at $\mathrm{C} / \mathrm{EBP}$ response element reduced iNOS promoter activity, but the overexpression of wild-type C/EBP- $\delta$ upregulated iNOS promoter activity. Similarly, LPS-mediated inductions of NO production and iNOS and C/EBP- $\delta$ protein levels in primary astrocytes were reduced effectively by the hypoglycemic or glucose-free condition. Therefore, these studies indicate that reducing the level of glucose or inhibition of G6PD may be helpful in amelioration of pathophysiologies associated with induction of iNOS and excessive production of NO.

Contrary to C6 rat glioma cells, hyperglycemic ( $6 \mathrm{gm} / \mathrm{l})$ conditions did not enhance the LPS-mediated responses in primary astrocytes. Although the difference between astrocytes and C6 rat glioma cells in conditions of minimal requirement of glucose for the full activation of iNOS gene expression is not understood fully, the demand for higher level of exogenous glucose in highly dividing C6 rat glioma cells as compared with primary cultured astrocytes may contribute toward the observed difference in iNOS gene expression. Previously, Ste-Marie et al. (2001) reported that iNOS gene expression is enhanced by hyperglycemic condition compared with normoglycemic condition in a rat model of permanent middle cerebral artery occlusion. However, the hyperglycemic condition did not affect iNOS gene expression in our in vitro studies with primary cultured astrocytes. The exact mechanism of these differences between the in vitro and in vivo conditions is not well understood at the present time; the possible involvement of other cell types in in vivo condition and the inflammatory reaction may contribute toward these differences.

Because glucose is one of the main energy sources for brain cells, its availability can affect cell viability and various signaling pathways, including the LPS-mediated signaling cascade. To know the cellular condition before LPS treatment, we examined the effect of glucose on cellular ATP level and LDH release or cell viability after $36 \mathrm{hr}$ of glucose treatment. In contrast to the dosedependent induction of iNOS gene expression by glucose, no differences were observed in ATP production or cell viability between 3 and $6 \mathrm{gm} / \mathrm{l}$ glucose, suggesting that the cellular level of ATP and related cell toxicity/viability influenced by extracellular glucose availability may not be the mediators in the observed glucose-dependent regulation of iNOS gene expression. However, we observed that the intracellular $\mathrm{NADPH} / \mathrm{NADP}^{+}$ratio paralleled the extracellular glucose concentration and induction of expression of iNOS. Furthermore, decreased intracellular $\mathrm{NADPH} / \mathrm{NADP}^{+}$after the treatment with DHEA, a known inhibitor of G6PD (a rate-limiting enzyme of the PPP) (Schwartz and Pashko, 1993), correlated with reduced iNOS expression as well as NO production. Because only high concentrations of DHEA $(50-100 \mu \mathrm{M})$, in which it acts as a uncompetitive inhibitor of G6PD, exhibited the inhibitory action on the iNOS gene expression induced by LPS as compared with relatively no effect at 
lower concentrations, its action likely may be attributable to the inhibition of G6PD rather than hormonal action. The involvement of G6PD in iNOS gene expression was supported further by the inhibition of NO production and iNOS protein expression by the treatment with the antisense DNA oligomer of G6PD mRNA. Although these results indicated the involvement of PPP in glucose-mediated upregulation of LPS-induced expression of iNOS, several previous studies have suggested that the inhibition or deletion of G6PD decreases the LPS-induced NO production without altering the iNOS protein levels (Laychock and Bauer, 1996; Tsai et al., 1998). Because NADPH plays a role, as a cofactor, in the synthesis of NO, NO production is reduced by NADPH depletion evoked by PPP inhibition at an enzymatic level. Our observations suggest that, as well as the inhibition at enzymatic level, iNOS gene expression also can be regulated by NADPH according to cell type.

DHEA and its synthetic analogs are known to function as antiproliferative agents in animal tumor models and malignant cell lines via inhibition of G6PD in PPP. The production of ribose moiety and NADPH by PPP is important for the generation of ribonucleosides or deoxyribonucleosides (Schwartz et al., 1988; Schwartz and Pashko, 1995), maintenance of glutathione redox balance, and synthesis of mevalonic acid. Neither exogenous cellpermeable glutathione analog nor ribose reversed the DHEAdependent inhibition of LPS-induced iNOS expression and NO production. Reduced synthesis of mevalonic acid by limitation of NADPH and acetyl-CoA in turn may limit the protein isoprenylation, impair the localization of small GTPase to the plasma membrane, and interrupt the subsequent signaling pathway (Schulz and Nyce, 1991; Schulz et al., 1992). However, extracellular glucose concentration had no effect on the membrane localization of hRas and RhoA (Fig. 6). Furthermore, the inability of farnesyl- or geranylgeranyl pyrophosphate treatment to bypass the glucose deprivation-mediated inhibition of iNOS induction and unexpected induction of iNOS by lovastatin, an inhibitor of 3-hydroxy-3-methylglutaryl CoA, strongly indicate that the isoprenylation (farnesylation and geranyl-geranylation) of proteins is not involved in the glucose or G6PD-dependent regulation of iNOS gene expression in C6 cells (Fig. 6). Although the exact mechanism of lovastatin-mediated enhancement of NO production has not been understood, similar observations were reported in smooth muscle cells, in which lovastatin-mediated enhancement of iNOS gene expression involved the inhibition of Rho small GTPase by lovastatin (Muniyappa et al., 2000; Yamamoto et al., 2003).

Several transcriptional factors, such as NF- $\kappa \mathrm{B}$, Fos/Jun, CREB, C/EBP, GAS, and IRF, have been described to be involved in the regulation of iNOS gene expression (Gao et al., 1997; Spink and Evans, 1997; Eberhardt et al., 1998; Marks-Konczalik et al., 1998; Zhang et al., 1998). Among these transcriptional factors, C/EBP DNA binding activity paralleled the changes in LPSstimulated responses by glucose or DHEA. Recently, Bhat et al. (2002) reported the possible involvement of C/EBP in iNOS gene regulation according to the inhibition of iNOS promoter activation by the overexpression of dominant-negative C/EBP protein. To confirm the involvement of C/EBP in the regulation of LPSinduced iNOS gene expression, we mutated the putative C/EBP response element- 2 site $(-171$ to approximately -163$)$ in iNOS promoter/enhancer, and we found that it significantly reduced the iNOS promoter activity in C6 rat glioma cells, as previously reported by Eberhardt et al. (1998). LPS or cytokine treatment of primary astrocytes is reported to induce the mRNA levels of two subtypes of C/EBP protein, especially the $\beta$ and $\delta$ forms (Cardi- naux et al., 2000). However, in contrast to the mRNA level in primary cultured astrocytes, $\mathrm{C} / \mathrm{EBP}-\beta$ in $\mathrm{C} 6$ rat glioma cells was expressed constitutively, and its level was not affected by either LPS or glucose. Moreover, an antibody against C/EBP- $\beta$ protein failed to supershift LPS-induced C/EBP DNA binding activity, indicating that $\mathrm{C} / \mathrm{EBP}-\beta$ may not be involved in the glucosemediated upregulation of iNOS. Because DNA binding activity of C/EBP- $\beta$ also was documented to be regulated by posttranslational modification (Poli, 1998), lack of C/EBP DNA binding activity may be attributable to the lack of activation of $\mathrm{C} / \mathrm{EBP}-\beta$ by post-translational modification. In contrast to $\mathrm{C} / \mathrm{EBP}-\beta$, the increase in C/EBP DNA binding activity by LPS was supershifted entirely by the antibody against C/EBP- $\delta$. The involvement of C/EBP- $\delta$ in glucose-dependent regulation of iNOS gene expression was supported by transient transfection studies in which overexpression of $\mathrm{C} / \mathrm{EBP}-\delta$ enhanced the iNOS promoter activity at 1 and $3 \mathrm{gm} / \mathrm{l}$ glucose, whereas it had no effect under glucose-free conditions. Under glucose-free conditions the impairment of energy production and increased toxicity or expression of $\mathrm{CHOP}(\mathrm{C} / \mathrm{EBP}-\delta$ homologous protein, also known as GADD153) may play a role in the lack of action of $C / E B P-\delta$. Consistent with this, $\mathrm{CHOP}$ expression was induced only under the conditions of glucose deprivation as well as high concentrations of DHEA. Because CHOP is known to be a negative regulator of C/EBP response element (Batchvarova et al., 1995; Ubeda et al., 1996), the inability to reverse the glucose deprivationinduced reduction of iNOS promoter activity by overexpression of $\mathrm{C} / \mathrm{EBP}-\delta$ may be attributable to the negative role of $\mathrm{CHOP}$ expressed under that condition. However, we cannot exclude the possible role of other transcription factors and signaling pathways in glucose-mediated regulation of iNOS gene expression.

In summary, we report that extracellular glucose plays a role in the LPS-induced iNOS gene expression and NO production. This regulation may be attributable to the involvement of G6PDdependent PPP and may indicate that the signal or signals for upregulation of expression of iNOS by extracellular glucose are mediated via the $\mathrm{C} / \mathrm{EBP}-\delta$ pathway. These studies also indicate that reducing the level of glucose or partial inhibition of G6PD may be helpful in amelioration of pathophysiologies associated with the induction of iNOS and excessive production of NO.

\section{References}

Barik S (1996) Site-directed mutagenesis in vitro by megaprimer PCR. Methods Mol Biol 57:203-215.

Batchvarova N, Wang XZ, Ron D (1995) Inhibition of adipogenesis by the stress-induced protein CHOP (GADD153). EMBO J 14:4654-4661.

Bhat NR, Feinstein DL, Shen Q, Bhat AN (2002) p38MAPK-mediated transcriptional activation of inducible nitric-oxide synthase in glial cells. Role of nuclear factor kappa B, cAMP response element-binding protein, CCAAT/enhancer-binding protein-beta, and activating transcription factor-2. J Biol Chem 277:29584-29592.

Candelise L, Landi G, Orazio EN, Boccardi E (1985) Prognostic significance of hyperglycemia in acute stroke. Arch Neurol 42:661-663.

Cardinaux JR, Allaman I, Magistretti PJ (2000) Pro-inflammatory cytokines induce the transcription factors $\mathrm{C} / \mathrm{EBP} \beta$ and $\mathrm{C} / \mathrm{EBP} \delta$ in astrocytes. Glia 29:91-97.

Dignam JD, Lebovitz RM, Roeder RG (1983) Accurate transcription initiation by RNA polymerase II in a soluble extract from isolated mammalian nuclei. Nucleic Acids Res 11:1475-1489.

Eberhardt W, Pluss C, Hummel R, Pfeilschifter J (1998) Molecular mechanisms of inducible nitric oxide synthase gene expression by IL- $1 \beta$ and cAMP in rat mesangial cells. J Immunol 160:4961-4969.

Gao J, Morrison DC, Parmely TJ, Russell SW, Murphy WJ (1997) An interferon- $\gamma$-activated site (GAS) is necessary for full expression of the mouse iNOS gene in response to interferon- $\gamma$ and lipopolysaccharide. J Biol Chem 272:1226-1230. 
Go KG, Prenen GH, Korf J (1988) Protective effect of fasting upon cerebral hypoxic-ischemic injury. Metab Brain Dis 3:257-263.

Green LC, Wagner DA, Glogowski J, Skipper PL, Wishnok JS, Tannenbaum SR (1982) Analysis of nitrate, nitrite, and $\left[{ }^{15} \mathrm{~N}\right]$ nitrate in biological fluids. Anal Biochem 126:131-138.

Hamilton MG, Tranmer BI, Auer RN (1995) Insulin reduction of cerebral infarction due to transient focal ischemia. J Neurosurg 82:262-268.

Ho YS, Howard AJ, Crapo JD (1988) Cloning and sequence of a cDNA encoding rat glucose-6-phosphate dehydrogenase. Nucleic Acids Res $16: 7746$

Iadecola C (1999) Overview: mechanisms of cerebral ischemic damage. In: Cerebral ischemia: molecular and cellular pathophysiology (Walz W, ed), pp 3-32. Totowa, NJ: Humana.

Iadecola C, Zhang F, Casey R, Nagayama M, Ross ME (1997) Delayed reduction of ischemic brain injury and neurological deficits in mice lacking the inducible nitric oxide synthase gene. J Neurosci 17:9157-9164.

Jaffrey SR, Snyder SH (1995) Nitric oxide: a neural messenger. Annu Rev Cell Dev Biol 11:417-440.

Laychock SG, Bauer AL (1996) Epiandrosterone and dehydroepiandrosterone affect glucose oxidation and interleukin- $1 \beta$ effects in pancreatic islets. Endocrinology 137:3375-3385.

Marks-Konczalik J, Chu SC, Moss J (1998) Cytokine-mediated transcriptional induction of the human inducible nitric oxide synthase gene requires both activator protein 1 and nuclear factor $\kappa$ B-binding sites. J Biol Chem 273:22201-22208.

McCarthy KD, de Vellis J (1980) Preparation of separate astroglial and oligodendroglial cell cultures from rat cerebral tissue. J Cell Biol 85:890-902.

Morigi M, Angioletti S, Imberti B, Donadelli R, Micheletti G, Figliuzzi M, Remuzzi A, Zoja C, Remuzzi G (1998) Leukocyte-endothelial interaction is augmented by high glucose concentrations and hyperglycemia in a NF- $\kappa$ B-dependent fashion. J Clin Invest 101:1905-1915.

Muniyappa R, Xu R, Ram JL, Sowers JR (2000) Inhibition of Rho protein stimulates iNOS expression in rat vascular smooth muscle cells. Am J Physiol Heart Circ Physiol 278:H1762-H1768.

Nagayama M, Zhang F, Iadecola C (1998) Delayed treatment with aminoguanidine decreases focal cerebral ischemic damage and enhances neurologic recovery in rats. J Cereb Blood Flow Metab 18:1107-1113.

Nathan C (1992) Nitric oxide as a secretory product of mammalian cells. FASEB J 6:3051-3064.

Nedergaard M (1987) Transient focal ischemia in hyperglycemic rats is associated with increased cerebral infarction. Brain Res 408:79-85.

O'Mahony D, Kendall MJ (1999) Nitric oxide in acute ischaemic stroke: a target for neuroprotection [editorial; see comments]. J Neurol Neurosurg Psychiatry 67:1-3.

Parmentier S, Bohme GA, Lerouet D, Damour D, Stutzmann JM, Margaill I, Plotkine M (1999) Selective inhibition of inducible nitric oxide synthase prevents ischaemic brain injury. Br J Pharmacol 127:546-552.

Poli V (1998) The role of C/EBP isoforms in the control of inflammatory and native immunity functions. J Biol Chem 273:29279-29282.

Prado R, Ginsberg MD, Dietrich WD, Watson BD, Busto R (1988) Hyperglycemia increases infarct size in collaterally perfused but not end-arterial vascular territories. J Cereb Blood Flow Metab 8:186-192.
Schulz S, Nyce JW (1991) Inhibition of protein isoprenylation and p21 ras membrane association by dehydroepiandrosterone in human colonic adenocarcinoma cells in vitro. Cancer Res 51:6563-6567.

Schulz S, Klann RC, Schonfeld S, Nyce JW (1992) Mechanisms of cell growth inhibition and cell cycle arrest in human colonic adenocarcinoma cells by dehydroepiandrosterone: role of isoprenoid biosynthesis. Cancer Res 52:1372-1376.

Schwartz AG, Pashko LL (1993) Cancer chemoprevention with the adrenocortical steroid dehydroepiandrosterone and structural analogs. J Cell Biochem Suppl 17G:73-79.

Schwartz AG, Pashko LL (1995) Mechanism of cancer preventive action of DHEA. Role of glucose-6-phosphate dehydrogenase. Ann NY Acad Sci 774:180-186.

Schwartz AG, Lewbart ML, Pashko LL (1988) Novel dehydroepiandrosterone analogues with enhanced biological activity and reduced side effects in mice and rats. Cancer Res 48:4817-4822.

Spink J, Evans T (1997) Binding of the transcription factor interferon regulatory factor-1 to the inducible nitric-oxide synthase promoter. J Biol Chem 272:24417-24425.

Ste-Marie L, Hazell AS, Bemeur C, Butterworth R, Montgomery J (2001) Immunohistochemical detection of inducible nitric oxide synthase, nitrotyrosine and manganese superoxide dismutase following hyperglycemic focal cerebral ischemia. Brain Res 918:10-19.

Tsai KJ, Hung IJ, Chow CK, Stern A, Chao SS, Chiu DT (1998) Impaired production of nitric oxide, superoxide, and hydrogen peroxide in glucose 6-phosphate-dehydrogenase-deficient granulocytes. FEBS Lett 436:411-414.

Ubeda M, Wang XZ, Zinszner H, Wu I, Habener JF, Ron D (1996) Stressinduced binding of the transcriptional factor CHOP to a novel DNA control element. Mol Cell Biol 16:1479-1489.

Voll CL, Auer RN (1988) The effect of postischemic blood glucose levels on ischemic brain damage in the rat. Ann Neurol 24:638-646.

Weigert C, Sauer U, Brodbeck K, Pfeiffer A, Haring HU, Schleicher ED (2000) AP-1 proteins mediate hyperglycemia-induced activation of the human TGF- $\beta 1$ promoter in mesangial cells. J Am Soc Nephrol 11:2007-2016.

Yamamoto T, Takeda K, Harada S, Nakata T, Azuma A, Sasaki S, Nakagawa M (2003) HMG-CoA reductase inhibitor enhances inducible nitric oxide synthase expression in rat vascular smooth muscle cells. Atherosclerosis 166:213-222.

Yip PK, He YY, Hsu CY, Garg N, Marangos P, Hogan EL (1991) Effect of plasma glucose on infarct size in focal cerebral ischemia- reperfusion [see comments]. Neurology 41:899-905.

Zador IZ, Hsieh CC, Papaconstantinou J (1998) Renal CCAAT/enhancerbinding proteins in experimental diabetes mellitus. Nephron 79:312-316.

Zhang H, Chen X, Teng X, Snead C, Catravas JD (1998) Molecular cloning and analysis of the rat inducible nitric oxide synthase gene promoter in aortic smooth muscle cells. Biochem Pharmacol 55:1873-1880.

Zhang Z, Yu J, Santon RC (2002) A method for determination of pyridine nucleotides using a single extract. Anal Biochem 285:163-167.

Zhu CZ, Auer RN (1994) Intraventricular administration of insulin and IGF-1 in transient forebrain ischemia. J Cereb Blood Flow Metab 14:237-242. 